the sunniest month occurs earlier. There is a marked tendency therefore in many localities for the summer to come upon us relatively quickly and for winter to be longer delayed.

It must be admitted that sunshine is only one meteorological factor to be considered in the selection of the best time and locality for holidays. Attention must also be paid to the frequency of rainfall, air temperature and sea temperature. For this reason the procedure adopted in the Hand- book of the British Health Resorts Association is a particularly happy one, for it gives the meteorological statistics of each health resort, together with comments on the climate from a medical aspect. It is a comforting fact, however, that in all parts of the British Isles the average annual duration of sunshine exceeds that of recordable rainfall, and that in the south-east of England the duration of sunshine is as much as seven times greater than that of recordable rain.

\title{
Percy Sladen Expedition to Lake Huleh
}

\section{By Roger Washbourn and R. F, Jones}

$\mathrm{T}$ HE Percy Sladen Expedition to Lake Huleh, Palestine, consisting of the present writers, has now returned. Biological investigations have been carried out during the greater part of the period August-December 1935. While much work remains to be done in the sorting and identification of the material, it is nevertheless felt that a preliminary account of the work may be of interest.

As stated in NATURE of October 5, 1935, p. 538, the region called the Huleh comprises two parts, which differ considerably (Fig. 1). The lake is at the southern end of the broad Huleh valley, and is separated from Tiberias by a low range of hills. It is bounded on the northern side by the swamp, which is for the most part an impenetrable tangle of papyrus, but which also contains channels of running water, and pools which may be up to an acre or so in extent. The lake covers approximately 5 square miles, and is of a general depth of 4-6 ft., with occasional deeper holes.

The lake shore is of gravel, where winter-running wadis have brought down much material from the surrounding hills, and where the direction of wave action keeps the stones clear from mud. In quiet places, under the shelter of the gravel spits, the shore is of mud, which in places becomes colonised by Phragmites. The bottom of the lake is everywhere of a light greyish mud. This mud is colonised by a great mass of aquatic plants, the stems of which may reach the surface of the water. The chief types present are species of Myriophyllum, Potomogeton, and Nuphar. They occur in large consociations, some of which are practically pure communities of a single species.

The water of the lake is fresh to the taste (accurate analyses of the chemical composition are being made), and the temperature is usually high. Fluctuations in temperature must be considerable; on one occasion the thermometer was observed to rise from $29^{\circ}$ to $31 \cdot 4^{\circ} \mathrm{C}$. in approximately $2 \frac{1}{4}$ hours.
The water is alkaline ; the $p \mathrm{H}$ being approximately 7.8-8.0 during the daytime. The oxygen content was found to be high, and the carbon dioxide content comparatively low.

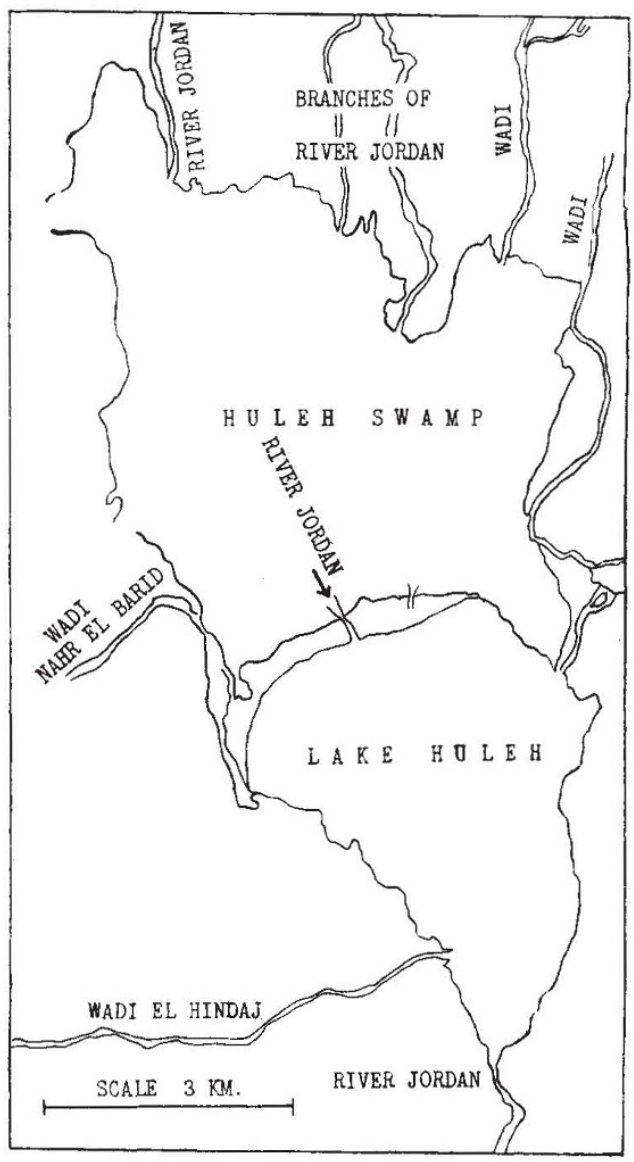

Fig. 1.

The phytoplankton was exceedingly dense, and was probably responsible largely for the constant colour of the lake water. The animal plankton on the other hand was meagre, and by no means 
corresponded with Barrois's ${ }^{1}$ estimation that it was "an abundant plankton". Quantitative hauls were not attempted owing to the difficulty of hauling in such a small depth of water, and where there is so much rooted plant growth. Systematic hauls were made every month, and are being continued throughout the year, through the kindness of the Jewish Colony at Yesud Hamalla.

The fauna consists of free-swimming, mud-living lithophilous and phytophilous types. Our collections of fish have yet to be investigated, but it does not appear that the fish fauna differs markedly from that of Lake Tiberias. Cichlid fishes are very common, and provide most of the fish for the small fishing community; cyprinids also occur, as does the siluroid Clarias. It seems, however, that the actual number of different species is not so high as in Lake Tiberias. In the mudliving community, the striking feature was the amazing abundance of the gastropod Melanopsis; one haul of the Petersen grab bringing up a hundred or more individuals.

Considering that a mother-ofpearl industry used to be carried on, and that Hornella describes the unionid lamellibranchs as very common, the numbers actually found were low. Corbicula, a common mollusc in Tiberias, is not common in Huleh. Other common animals living in the mud of the lake bottom were many small oligochætes and chironomid larvæ. The stone-living fauna comprises one species of polyzoan, probably Fredricella, ephemerid nymphs of the genus Conis, a species of leech. Melanopsis and Melania are also very numerous.

Along the northern end of the lake there is a broad mud bank which runs also some way down the western side. This is colonised by a very dense zone of Nuphar, mixed with Ceratophyllum. To the west this is succeeded on the landward side by Phragmites, to the north it may be succeeded by Papyrus or Phragmites.

In this region, the fauna differs markedly from that of the lake; typical lake forms are replaced by others which occur in the swamp. The lake gastropods occur in numbers in the Nuphar zone, where together with various insect larvæ they are the commonest animals. The Nuphar zone itself supports a fauna : a coleopteron, several diptera and a lepidopteron. In the Phragmites the Melania and Melanopsis cease to occur, and one finds various species of smaller gastropods, such as also occurin the swamps. Conis is absent, and the whole character changes completely.
The swamp proper sharply limits the northward extension of the lake. It is approximately three miles broad, and extends northward for another five miles before ending more or less abruptly in reclaimed land, the latter being tilled and used for millet growing.

The most common consociation of the swamp is dominated by Cyperus papyrus. This community covers many square miles, and may be found under conditions varying from complete submergence of the rhizomes in water, to cases in which these organs are growing more or less superficially in damp peat. In the submerged state, the thick rhizomes are usually so intermingled as to form a more or less floating raft, usually firm enough to bear the weight of a man, 
more in the submerged condition. The papyrus can grow to a height of fifteen feet, and in spite of the fact that, where it is most dense, it intercepts much of the direct light, enough light passes through to allow the development of a sub-flora. The taller plants, such as Lythrum salicaria and Lycopus europceus, may reach much of the direct light; but in the lower vegetation stratum there is little else beside a species of fern which grows in great profusion.

The open water system of the swamp is made up of the running water of the channels, the pools and the River Jordan. Fringing the channels there may be Ceratophyllum with Utricularia and algæ floating among its crowded upper branches. Continual disturbance of the water and the bottom by Arabs prevents to a great extent the growth of

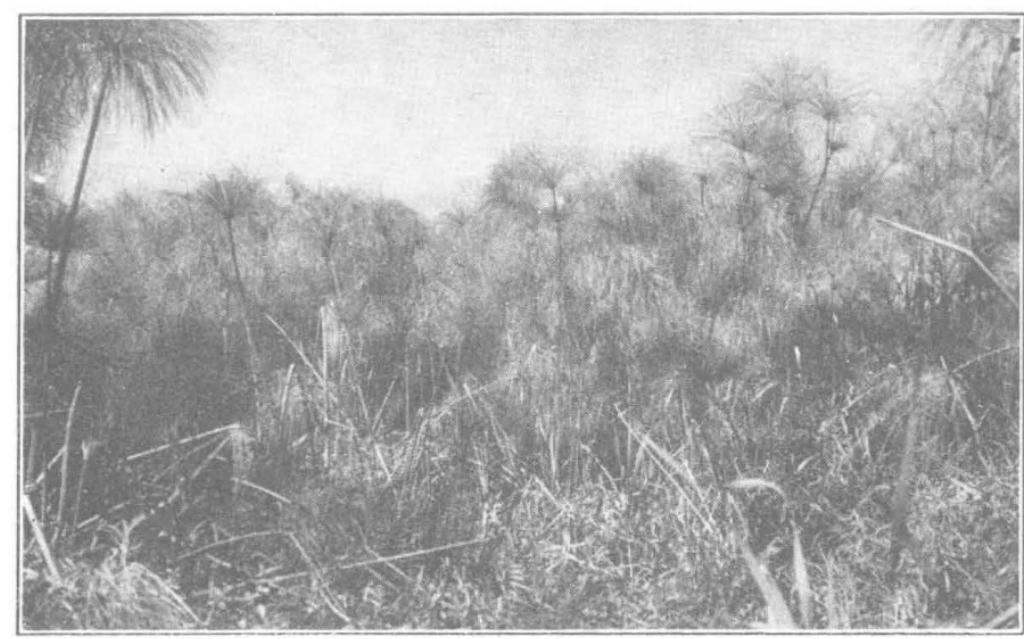

Fig. 3. A clearing in the papyrus swamp, Lake Huleh. Photograph by R. Washbourn.

per litre). The $p H$ was always neutral or slightly alkaline (about $p H$ 7.0) and with an alkali reserve of $0.004 N$, gives a high carbon dioxide content. The temperatures were all comparatively low, and did not fluctuate very greatly. This suggests that the water may be derived from springs in the swamp itself. Furthermore, on analysis, the water samples from various portions of wet swamp were found to show roughly the same characteristics as that of the channels. It may be that the presence of water in certain parts of the swamp in summer is due to the proximity of channels or springs.

The fauna of the channels may depend in great measure upon the growth of a fringing zone of Ceratophyllum. The fauna was meagre; a few Entomostraca, Hemiptera and cyprinodont fishes occurring, with Anopheles larvæ in the quieter bays. In the wetter parts of the swamp gastropod molluses were numerous, a number of different species being present, including one species very similar to Ancylus. A prawn, the crab Potamos and the turtle Clemmys were common.

It is not within the scope of this article to describe the fauna of the drier part of the swamp, for it takes on a much more terrestrial facies : spiders, Lepidoptera, Or. thoptera, etc., making their way in from the surrounding country. Mention may, however, be made of thenumerous earthworms, which must have a very considerable modifying influenceon the peatsoil.

the small plants of Ceratophyllum in these channels ; but once they have fallen into disuse a dense mass of Ceratophyllum soon grows up and blocks them.

The pools may be bordered either by Phragmites or by papyrus; they are often covered with Nuphar and Ceratophyllum; while in many pools Nymphoea is common. It is interesting that Nymphoea is confined to the swamp and that it was never found in the lake.

Along the stretch of the Jordan which passes through the swamp the banks are slightly raised and are generally covered with papyrus. Along the edge of this papyrus in very deep water there may be a fringing zone of Polygonum spp.; Cladium mariscus is often to be found near the river bank. On the bank there may be various grasses; Cyperus spp. (differing from papyrus), and Typha spp. Towards the swamp these are usually succeeded by Phragmites or papyrus.

The composition of the water of the swamp differs markedly from that of the lake. The oxygen content, as might be expected, was very low (1-2 c.c.
It is believed that the comparatively poor fauna of the swamp is due to the great fluctuations in the water-level and to the high carbon dioxide content and low oxygen content of the water. All these factors have been shown to be physiologically of great importance to the majority of animals.

The scope of the expedition was limited by the number of the personnel; and certain groups were perforce omitted from the collections. The objects of the work were to investigate the flora and fauna for forms of Ethiopian origin, to study in particular the plant ecology of a papyrus swamp, and to describe the distribution of such animals as were found. We hope that the material collected may throw fresh light on the problem of the origin of the Jordan Valley fauna.

Our thanks are due to the Hebrew University of Jerusalem for the valuable help they gave us, in particular to Dr. G. Mer, of the Malaria Research Station, Rosh Pinna.

\footnotetext{
${ }^{1}$ T. Barrois, “Contributions à l'étude de quelques lacs en Syrie".
} Rev. Biol. du Nord France, vol. 6 